IZA DP No. 7653

The Wider Economic Impacts of High-Skilled Migrants: A Survey of the Literature

Max Nathan

September 2013 


\title{
The Wider Economic Impacts of High-Skilled Migrants: A Survey of the Literature
}

\author{
Max Nathan \\ SERC, London School of Economics, \\ NIESR and IZA
}

Discussion Paper No. 7653

September 2013

\author{
IZA \\ P.O. Box 7240 \\ 53072 Bonn \\ Germany \\ Phone: +49-228-3894-0 \\ Fax: +49-228-3894-180 \\ E-mail: iza@iza.org
}

Any opinions expressed here are those of the author(s) and not those of IZA. Research published in this series may include views on policy, but the institute itself takes no institutional policy positions. The IZA research network is committed to the IZA Guiding Principles of Research Integrity.

The Institute for the Study of Labor (IZA) in Bonn is a local and virtual international research center and a place of communication between science, politics and business. IZA is an independent nonprofit organization supported by Deutsche Post Foundation. The center is associated with the University of Bonn and offers a stimulating research environment through its international network, workshops and conferences, data service, project support, research visits and doctoral program. IZA engages in (i) original and internationally competitive research in all fields of labor economics, (ii) development of policy concepts, and (iii) dissemination of research results and concepts to the interested public.

IZA Discussion Papers often represent preliminary work and are circulated to encourage discussion. Citation of such a paper should account for its provisional character. A revised version may be available directly from the author. 


\section{ABSTRACT}

\section{The Wider Economic Impacts of High-Skilled Migrants: A Survey of the Literature ${ }^{1}$}

In recent years, the economics of migration literature has shown a substantial growth in papers exploring host country impacts beyond the labour market. Specifically, researchers have begun to shift their attention from labour market and fiscal changes, towards exploring what we might call 'the wider effects of migration' on the production and consumption sides of the economy - and the role of high-skilled migrants in these processes. This paper surveys the emerging 'wider impacts' literature, including studies from the US, European and other countries. It sets out some simple, non-technical frameworks, discusses the main empirical findings and identifies avenues for future research.

JEL Classification: $\quad$ G23, G24, J15, J61, L5, L26, M12, M13, O31, O32, R11

Keywords: immigration, high-skill migrants, innovation, entrepreneurship, investment, productivity, cities

Corresponding author:

Max Nathan

London School of Economics

Houghton St

London, WC2A 2AE

United Kingdom

E-mail:m.a.nathan@Ise.ac.uk

\footnotetext{
${ }^{1}$ This paper is based on research commissioned by the UK Migration Advisory Committee (MAC), and conducted by the author, Heather Rolfe and Carlos Vargas-Silva. Jonathan Portes provided helpful comments on previous drafts. The financial support of the MAC is gratefully acknowledged. The paper represents the views of author, not the MAC. Any errors and omissions are my own.
} 


\section{1/ Introduction}

In recent years, the economics of migration literature has shown a substantial growth in papers exploring host country impacts beyond the labour market. Specifically, researchers have begun to shift their attention from labour market and fiscal changes, towards exploring what we might call 'the wider effects of migration' on the production and consumption sides of the economy - and the role of high-skill migrants in these processes (Chiswick 2005; Huber, Landesmann et al. 2010; Kerr and Kerr 2011; George, Lalani et al. 2012; Hanson 2012; Lewis 2012; Kerr 2013).

There are many reasons for this shift: I highlight a few here. One important factor is the realisation that over the past few decades, many developed countries have experienced not just one-off migration 'shocks' but continuous 'waves', leading to permanent changes in population and workforce composition. In turn, that has prompted many researchers to look beyond the short-term impacts of new arrivals (about which we know quite a lot) towards longer term, dynamic effects (about which we know much less). At the same time, empirical research on migrants in the labour market has repeatedly demonstrated that high skilled migrants may play very different roles from those in other skill cells (Dustmann, Glitz et al. 2008). Given the demographic backdrop, much of the emerging research has also emphasised the diversity that migration brings, and the potential affordances of diversity in different economic and spatial contexts - including the emergence of 'super-diversity' in some urban neighbourhoods (Vertovec 2007; Nathan 2012).

Links between high-skilled immigration and innovation have been one major focus of this 'wider impacts' literature to date (Kerr and Kerr 2011; Kerr 2013). There is also increasing interest in highskilled migrant entrepreneurship, for example 'transnational entrepreneurs' and start-up founder teams (Acs and Szerb 2007; Saxenian and Sabel 2008; Drori, Honig et al. 2009; Honig, Drori et al. 2010; Kerr 2013). This is a shift from a long tradition of research on migrant and ethnic entrepreneurship, which has tended to focus on small business formation in non-tradeable sectors such as retail and leisure (Light 1984; Rath and Kloosterman 2000; Kloosterman and Rath 2001; Ram and Jones 2008).

Similarly, research looking at the connections between migration, trade and investment flows is increasingly focused on specific high-skill diasporic communities as enablers of market access (Docquier and Rapoport 2012; Hanson 2012). Other research has looked at impacts on the prices of housing and other local goods/services, although these studies are rather less common. 
In many countries, particularly the UK, migrant inflows have been spatially uneven, with urban areas - and big cities in particular - recording the largest stocks of new arrivals. High-skilled migrants may also be disproportionately attracted to urban locations with large skilled labour markets and good access to new ideas, collaborators and start-up capital. Silicon Valley, with its prominent entrepreneurial South / South East Asian communities, is the best-known example (Saxenian and Sabel 2008). There has also been a growing interest in local level effects, with geographers, economists and others exploring how migration is influencing city life and urban economies (Card 2010; Smallbone, Kitching et al. 2010; Syrett and Sepulveda 2011; Nathan 2012).

The 'wider impacts' literature is still a young field, with the vast majority of published material appearing in the last five years, and there is a great need for further research. The 150-odd studies reviewed here thus involve a mixture of quantitative and qualitative approaches, drawing on largescale data sets, surveys, case studies and in some cases historical analysis. The field focus is on economics, but papers are also drawn from other relevant fields (such as geography, urban studies, business and management, entrepreneurship, innovation, and housing studies). This review does not pretend to be comprehensive: it is based on research originally commissioned by the UK Migration Advisory Committee (MAC), and follows the broad outlines of that brief.

The rest of the paper is structured as follows. Section 2 sets out a simple, non-technical, framework for thinking about the impacts of high-skilled migration on the receiving country. It contrasts a static 'labour markets' setting with a more dynamic 'growth' setting, in which high-skilled migrants may have economic impacts on both the production and consumption sides of the economy, through a number of different channels. Section 3 discusses some of these channels in more detail, focusing on entrepreneurship, innovation, investment (on the production side) and prices and public services (on the consumption side). Section 4 gives an overview of empirical studies for these channels. Section 5 briefly discusses the role of skilled migration in cities and on the spatial economy. Section 6 sets out some conclusions and identifies some of the many avenues for further research.

\section{2/ The economic impacts of skilled migration: a simple framework}

Analysis of the economic impacts of migration has tended to concentrate on labour market or fiscal impacts (Kerr and Kerr 2011). These analyses typically feature neoclassical settings, where migrants have single roles (say, workers or consumers of public services), modelling is restricted to one-off shocks and adjustment periods, and the field of impact is narrowly defined (Borjas and Doran 2012). 
Such an approach ignores or underplays several wider economic impacts of migration, especially those involving skilled migrants. To illustrate this point I adapt Chiswick (2005) Huber et al (2010) and Hanson (2012) to contrast a static, labour demand-and-supply setting with a dynamic growth setting.

First, consider the static 'labour markets' setting. In a given host country, a set number of firms' productivity is determined by labour costs, plus fixed technological capacity and trade costs. Migrants enter the country solely as workers, and are perfect substitutes with natives. In this model, skilled migration has limited economic impacts. In small open economies (such as the UK) a net migration shock will increase the labour supply, and temporarily bids down the average native wages. If wages are sticky, native employment may also fall. Over time, natives' wages and employment rates should readjust to their pre-shock levels via international capital flows, and the expansion of labour-intensive sectors (Card 2005; Dustmann, Glitz et al. 2008). If the migration shock consists of (un)skilled workers, this will depress the relative wages of (un)skilled natives, and raise those of (higher) lowerskilled natives. For firms, migration helps labour productivity by cutting labour costs. But migration has no wider effects, as other productivity shifters are exogenous.

Next, consider a dynamic 'growth' setting. Here, firms can change their labour costs, and their innovative capacity and trading environment. Endogenous growth models show how human capital helps generate new ideas, which advance the technological frontier and feed into productivity gains (Lucas 1988; Romer 1990). Firms that invest in research and development can thus build innovative capacity and raise productivity, but may face informational / financial constraints in doing so. Trade costs are now partly determined by information asymmetries and co-ordination problems, and firms that can lower these will raise productivity (and subsequently gain market share) (McCann and Acs 2011; Hanson 2012). Existing firms also face competition from entrepreneurs, who create businesses around new ideas (Schumpeter 1962; Aghion, Blundell et al. 2009).

In this setting, skilled immigration - in particular - has several impacts on both the production and consumption sides of the economy. For example, access to knowledge and ideas may be highly uneven, national entrepreneurial 'capacity' may vary, and features of innovation ecosystems may constrain ideas diffusion (Acs, Audretsch et al. 2004; Agrawal, Kapur et al. 2008). This opens up space for skilled / entrepreneurial individuals to contribute to knowledge generation, and for international networks to help diffuse innovations across space. Equally, complex global production chains imply high search, transaction and management costs (Mudambi 2008). Intermediary actors such as skilled migrants - may help firms access new markets, and co-ordinate complex business activities (Saxenian and Sabel 2008). Similarly, production complementarities between skilled migrants and natives may raise the return on capital, and in doing so, generate higher savings and FDI 
inflows (Chiswick 2005; Peri and Sparber 2011). All of these channels will contribute to productivity and/or competitiveness, in the sense of increased market share for firms in the receiving country (Hanson 2012).

These channels require relaxing some assumptions from the static framework (Huber, Iara et al. 2010). Specifically, migrants can act as entrepreneurs and investors as well as workers; migrants have financial, social and network capital, as well as human capital; and migrants and natives can be imperfect substitutes. ${ }^{2}$

When thinking about these issues it is useful to think of 'production' and 'consumption' side impacts (Nathan 2012). Production-side channels impact productivity and its drivers, and may operate at various levels. First, individual migrant status may pre-select entrepreneurial individuals, who contribute to new business formation and/or uncover new market niches (Bonacich 1973; Honig, Drori et al. 2010); or very high human capital 'stars' who contribute to innovate (Borjas 1987; Zucker and Darby 2007). Individual high net worth entrants may also be able to ease domestic firms' capital constraints.

Second, firms hiring a 'star' researcher or scientist may be able to significantly raise their productivity - at the expense of other competing firms (Hanson 2012). More broadly, diverse workforces may have an advantage in generating innovative ideas, particularly in skill and knowledge-intensive sectors that generate significant value-added (Fujita and Weber 2003; Page 2007; Nathan and Lee Forthcoming). Firms in these high-value sectors may further benefit from skilled migrants' access to co-ethnic networks, which may assist knowledge diffusion, or lower co-ordination costs and thus improve international market access (Kapur and McHale 2005; Saxenian 2006; Saxenian and Sabel 2008; Foley and Kerr 2013).

Third, we may see indirect / spillover effects at sector or market level. Migrant entrepreneurs may spur competition in domestic markets, forcing incumbents to innovate and raise their productivity (Aghion, Dewatripont et al. 2012). Diversity and diaspora externalities within specific firms may also assist all firms' innovation, via further knowledge spillovers across sectors (Jacobs 1969; Jaffe 1996). Similarly, activities of migrant entrepreneurs and investors, and changes in specific firms' market access, may shift overall patterns of trade and FDI between home and host countries (Docquier and Rapoport 2012).

\footnotetext{
${ }^{2}$ There is strong empirical evidence for the last of these, particularly for skilled migrants. See e.g Manacorda et al (2012) for the UK or for the US, Peri and Sparber (2011).
} 
On the consumption side, impacts of skilled migration are harder to distinguish. At a local level, high levels of net migration may raise the level of demand for non-tradeable goods, and/or change patterns of demand in these sectors (Mazzolari and Neumark 2012). Migration may also increase competition for goods with inelastic supply such as housing, raising local prices. (Saiz 2003; Ottaviano and Peri 2006).

\section{3/ Impacts channels for skilled migration: theory}

This section sets out production side and consumption side impact channels of skilled migrants in more detail, focusing on entrepreneurship and investment channels.

\section{1 / Entrepreneurship}

There is a well-established 'ethnic entrepreneurs' literature that links migrant and minority communities to self-employment, entrepreneurial activity and small business formation. Migrant and minority ethnic communities have a generally higher propensity to be self-employed (Light 1984; Baycan-Levent and Nijkamp 2009). Levels of enterprise are influenced by access to opportunities, individual and group characteristics (such as ethnic and class 'resources'), and emergent strategies (Aldrich and Waldinger 1990). Urban location may help ethnic enterprise because of urban demography (larger downstream markets) and/or greater economic opportunities (greater matching, sharing and learning economies) (Kloosterman and Rath 2001; Light 2004).

Ethnic entrepreneurship may be reactive: exclusion from mainstream economic life may force groups into developing new businesses, products and services (Kloosterman and Rath 2001). Conversely, community characteristics and attitudes may drive proactive entrepreneurship. For example, 'middleman minority' [sic] status may help individuals create business opportunities between social groups (Bonacich 1973). Alternatively, entrepreneurs may benefit from externalities of migrant enclaves, such as better access to information or finance (Edin, Frederiksson et al. 2003).

This literature is not concerned with human capital per se: individual migrant entrepreneurs may be highly skilled individuals, or low-skilled actors entering sectors with low entry barriers (Sepulveda, Syrett et al. 2011). A more recent set of studies focus more closely on skilled migrants, and identifies two further channels. As set out in the Roy model, the migration decision involves balancing risks against expected future returns, so that the migration decision may positively select highly skilled and/or highly entrepreneurial individuals (Borjas 1987). Migrants also face a lower opportunity 
cost of investing in new skills or ways of working, so migrants may be more flexible economic actors - for example, more willing to engage in disruptive business models (Duleep, Jaeger et al. 2012). Skill-biased migration policies will then help to bring in highly skilled and/or entrepreneurial 'stars' into host economies.

In closed economies, externalities from co-ethnic enclaves or groups may be limited by group size or external constraints (see below). However, under globalisation, transnational diasporic groups may provide an important source of social and cultural capital (Docquier and Rapoport 2012). Equally, highly skilled and motivated transnational entrepreneurs can set up new enterprises in a number of locations, or act as go-betweens between domestic firms and those in 'home' countries (Kloosterman and Rath 2003; Zhou 2004; Saxenian 2006; Drori, Honig et al. 2009; Honig, Drori et al. 2010).

In theory, all four of these channels may be constrained. First, apparent effects of skilled migrant / minority status may simply collapse to individual human capital endowments, or wider structural conditions (Hunt and Gauthier-Loiselle 2010). Second, discrimination may limit opportunities for business creation, even in reactive contexts; and may limit opportunities for middleman-type arbitrage. Third, in closed economy settings, enclave externalities may also be limited by size (the smaller the group, the smaller the set of within-group matches (Zenou 2011)). Finally, disapora/enclave affordances may be weaker than other factors (such as class or family ties); and some trans-national communities may be more organised and effective than others.

The main effect of migration-entrepreneurship channels will be on levels of business creation. There may also be wider impacts. First, new firm entry increases market competition, and may stimulate incumbent firms to innovate in response (Aghion, Bloom et al. 2005). Second, net firm entry itself accounts for a large share of national productivity growth, so higher levels of entrepreneurship may be short-term productivity-enhancing (Lewis 2012).

The literature does not discuss distributional impacts of skilled migrant entrepreneurship, but we can sketch out some issues here. One key point is whether new migrant businesses add to or displace existing firms. To the extent that (skilled) migrants identify new opportunities, the net effect is likely to be additional; however, to the extent that new opportunities are also disruptive, additionality is limited. More broadly, the process of firm entry may be welfare-enhancing for consumers, if entrants stimulate stronger incumbents to innovate and weaker firms to exit (Aghion, Bloom et al. 2005). However, this incurs welfare losses for owners and staff in lagging domestic firms. 


\section{2 / Investment}

Skilled migrants may play a number of investment-related roles, both at the level of individual firms and in terms of higher-level patterns of trade and FDI. However, while trade and FDI mechanisms are relatively well covered in the literature, individual-level channels are much less discussed.

Migrants who are high net-worth individuals, and who enter a host economy as investors should be able to ease capital constraints for domestic firms. Related to this, investment may trigger knowledge spillovers between investors and recipients: skilled investors who have sector-specific expertise may also have impacts on recipient firms' innovation and productivity (Markusen and Venables 1999; Markusen and Trofimenko 2009; Malchow-Møller, Munch et al. 2011; Giannetti, Liao et al. 2012). ${ }^{3}$

Over time, migration may alter the level and pattern of trade and foreign direct investment (FDI) flows between host and home countries. Incomplete information creates trade frictions: migrants bring improved international market knowledge, leading to better matching of buyers and sellers (Rauch and Trindade 2002; Rauch and Casella 2003; Peri and Requena 2010). Diasporic /co-ethnic networks also raise trust, providing effective means of contract management and enforcement (Javorcik, Özden et al. 2011). Alongside these 'information channels', migrants also create a 'preference channel', by demanding goods from the home country (Combes, Lafourcade et al. 2005).

The size of trade effects with a given sending country will partly depend on the size of migrant community in the receiving country. Skilled migrants may also play particularly important roles in these channels: skilled migrants are likely to have both better information on business opportunities, better social capital and professional networks (Kugler and Rapoport 2007; Saxenian and Sabel 2008; Docquier and Lodigiani 2010; Mundra 2012).

As with trade flows and FDI inflows, skilled migrants can also provide domestic investors with additional information on 'home' market investment opportunities, reducing transaction costs (LeBlang 2011; Pandya and Leblang 2012). Skilled migration may thus help reduce equity home bias (Foad 2011). Similarly, skilled migrants may provide matching and brokering functions that help multinational firms develop and manage overseas investments (Foley and Kerr 2011).

As with the entrepreneurship channel, there are a number of potential constraints on these channels, so that skilled migration is a priori ambiguous in its effects on investment. First, discrimination from

\footnotetext{
${ }^{3}$ By contrast, low-skill migration may act as a substitute for investment in physical capital (see 3.5).
} 
majority groups may limit migrant investor entry, or investment opportunities in host markets. Second, it is important to disentangle co-ethnic networks from other socio-cultural resources that skilled / well-off individuals may possess. Third, some migrants may more valuable than others those from countries where strong trade links already exist may bring little or no additional advantage (Girma and Yu 2002). Finally, theoretical frameworks are often silent about how domestic firms interact with migrant investors, or access the diasporic communities that may influence trade and investment flows.

\section{3/ Innovation}

Innovation is 'the successful exploitation of new ideas' (Department of Innovation Universities and Skills 2008), and involves both ideas generation and commercialisation (Fagerberg 2005). In turn, this suggests a number of ways in which skilled migrants might influence innovative activity.

First, as in the entrepreneurship channel, the migration decision might positively select high-skilled 'stars' (Borjas 1987). Entry may be via skilled migration policies or via higher education, especially into postgraduate courses (Chellaraj, Maskus et al. 2008; Stuen, Mobarak et al. 2012) and faculty research positions (Hunt 2011). Research-intensive fields such as science and engineering are particularly relevant for these star-innovation channels (Stephan and Levin 2001). Star scientists have a disproportionate impact on knowledge creation, by raising research grants and engaging in multiple collaborations, especially with other stars (Zucker and Darby 2007).

Second, at firm level, the ethnic / cultural diversity of teams may generate externalities that contribute to knowledge creation. Specifically, diverse teams may be more effective than homogenous teams in problem-solving or generating new ideas, as they leverage a wider pool of perspectives and skills (Page 2007; Berliant and Fujita 2009). These dynamics may be particularly important in research-based or knowledge-intensive activities (Fujita and Weber 2003).

Third, diasporic networks may contribute to knowledge diffusion, in similar ways to their potential effects on entrepreneurship, trade and FDI flows. Networks reduce information and communication costs as knowledge is exchanged through groups with greater mutual understanding and trust; they may also aid knowledge spillovers by stimulating citations and ideas recombination through the network structure (Jaffe and Trajtenberg 2002; Kerr 2008; Docquier and Rapoport 2012).

Skilled migration may also have wider, indirect effects on innovation. As above, if migrant entrepreneurship leads to significant new firm entry, this may lead incumbents to innovate. Withinsector spillovers may also trigger wider spillovers between sectors, particularly in urban environments 
(Jacobs 1969; Duranton and Puga 2001). Knowledge spillovers tend to be highly localised (Jaffe, Trajtenberg et al. 1993; Audretsch and Feldman 1996). This suggests that at least some immigrationinnovation effects may be spatially clustered, and largest in urban areas or research-rich locales (such as university towns). But diaspora channels will be much less distance-sensitive.

Against this, there are reasons why migration-innovation channels may be limited. A diverse team may find it harder to communicate, and levels of trust may also be lower (Alesina and Ferrara 2005). Diverse organisations may also face discrimination from other market actors. As a result, organisations may find it harder to make decisions or allocate resources, and the quality of those decisions may be lower than in more homogenous organisations. Similarly, if knowledge flows only within diasporic communities, this will limit the scope of knowledge spillovers.

Borjas and Doran $(2012 ; 2012)$ also suggest that innovation-related externalities can co-exist with distributional losses for some groups. For example, if research jobs and lab space is limited, migrant inventors may compete with native inventors for these resources. Even if there are gains from individual stars, networks or group-level diversity, some 'losers' may need to shift field within a given career ('cognitive mobility') or exit into other (potentially less attractive) activity. Note that while cognitive mobility may be welfare-bad for movers in the short term, movers may gain long term. ${ }^{4}$ As Kerr (2013) points out, it is unclear whether field / career switching of this kind can be considered 'crowding out' in a normative sense.

\section{4 / Other production-side channels}

Two other production-side channels are less well covered in the literature, but are worth mentioning briefly here.

First, if firms' production functions are endogenous to changes in the labour supply, then employers may react to immigration by making changes to production technology. Lewis (2011) sets out a model in which low-skilled migrants are substitutes for capital investment. Migration-induced labour supply shocks then induce firms to develop more labour-intensive production techniques. This smoothes any negative wage impacts of low skill migrants, but may constrain longer-term gains in firms' TFP via capital upgrading. Conversely, high-skilled labour may be complementary to capital investment - for example, skilled researchers may complement lab equipment for scientific research. This suggests an additional channel for high-skill migration may induce TFP gains on top of those already discussed above (Paserman 2008; Kangasniemi, Mas et al. 2012; Peri 2012).

\footnotetext{
${ }^{4}$ In the case of Borjas and Doran's study, many movers leave academia to work in hedge funds.
} 
A second source of TFP gains is production complementarities via increased task specialisation. If migrants and natives are imperfect substitutes, then high-skill migration may induce both skill groups to shift tasks in a team or workforce setting (Peri and Sparber 2011; Lewis 2012). In this case, skilled migration may lead to 'cognitive mobility' by individual native workers (see section 4.4) but human capital spillovers and TFP gains at the firm level.

\section{5 / Consumption side}

Impacts of migration on the consumption side largely focus on fiscal impacts (see Card (2010) and Kerr and Kerr (2011) for reviews). Here, I briefly review how skilled migration might influence prices, the variety of goods and services, and public service usage.

\section{Prices}

In theory, migration has an ambiguous effect on the prices of goods and services (Frattini 2008). Migration might lower production costs through cheaper labour and/or production externalities, particularly in labour-intensive sectors (Cortes 2008; Baghdadi and Jansen 2010). In turn, this should lower the prices of goods and services in those sectors. However, migration also increases population size and so raises the level of consumer demand. These 'scale effects' are likely to be biggest for nontradeable sectors (Mazzolari and Neumark 2012). If inflows are large enough to facilitate economies of scale in production, prices may fall. Alternatively, if goods are inelastically supplied, such as housing, migration may lead to higher prices (Saiz 2003; Saiz 2007).

The supply-side effect of skilled migrants on prices is harder to determine. The general migrant population may cluster in labour-intensive sectors - predominantly non-tradeables - helping to lower production costs, wages and prices in those sectors (Cortes 2008). However, skilled migrant entrepreneurs and investors likely operate mainly in higher-value, tradeable sectors where local conditions matter less. This suggests that supply-side impacts on prices are likely to be limited.

Demand-side impacts of migrants on goods such as housing will depend on a) the size of the inflow b) migrant preferences and behaviour c) producer response d) native response. In the short term, migrants and natives compete for a fixed stock of housing, increasing costs. In the longer term, developers respond by building more, offsetting these price movements (Saiz 2007; Card 2010). Migrant/native preferences may also differ. Migrants may be most likely to rent, at least in the short term, so impacts on house prices may be limited for these reasons. Within cities, house prices and rents may also be affected by native response - for example, if natives leave areas where migrants live, so that net population falls, this will likely put downward pressure on prices and rents in those 
areas (Saiz 2011; Saiz and Wachter 2011). Higher overall demand at area level may then be combined with by greater price variation and increased segregation within that area. Again, it is not straightforward to identify specific impacts of skilled migrants: poorer/less-skilled migrants are more likely to share properties, and so consume less housing than natives. Higher-skilled migrants might then consume similar quantities of housing to natives.

Mix / variety

If migrants have different preferences to natives, this will generate 'composition effects' on the set of goods and services provided (Mazzolari and Neumark 2012). Mazzolari and Neumark also suggest that migrants may have comparative advantage in production on 'ethnic' goods, through specific knowledge and/or entrepreneurial skills. In this scenario, migration leads to both greater variety and higher migrant business entry: we would expect skilled migrant entrepreneurs to play an important role in these channels. A native population with a taste for diversity may also support these composition effects (Florida 2002; Gordon, Whitehead et al. 2007). Conversely, if migrant inflows are large and lead to substantial increases in demand, this may trigger production-side economies of scale which lead to producer consolidation (Mazzolari and Neumark 2012). In this case, the variety of goods and services may rise but the variety of producers shrinks (for example, if small shops are replaced by supermarkets).

\section{$\underline{\text { Public services }}$}

Public service impacts of migration can be framed similarly to private goods and services, with the critical difference that production cost shifts and resource competition will not be reflected in user prices, but forms of non-price rationing. Migration 'shocks' which change population composition may also lead to short term mismatches between user demand and services offered, while in the longer term producers respond by switching the service mix (in schools, say, by providing greater support for English as a Second Language (ESOL) provision). Again, the key issue is whether skilled migrants have distinctive preferences and patterns of use. We might speculate that some high-skilled (and better-off) migrants might be less likely than natives to use public services. But ultimately this is an empirical question. 


\section{4/ Impacts channels for skilled migration: empirics}

\section{1 / Entrepreneurship}

The international evidence - mainly from the US - highlights the importance of large and skilled diasporic communities in influencing firm formation in host countries.

First, a number of descriptive and case studies trace links between US-based diasporas and transnational entrepreneurs and 'home' countries such as India, China, Taiwan, Ireland and Israel (Kapur and McHale 2005; Saxenian 2006; Saxenian and Sabel 2008). These studies typically find positive connections between diaspora presence, US firm formation, and a range of wider benefits to US firms, although they do not identify causal links (discussed further in sections 5.2 and 5.3).

Second, structured surveys examine high-skill communities in the US. Saxenian (2002) finds that that skilled migrants make up 1/3 of the Bay Area's engineers, with two-thirds born in Asia and three quarters of these from China and India. In 1998, Chinese and Indian engineers were senior executives at one quarter of Silicon Valley's technology businesses; these immigrant-run companies collectively accounted for more than $\$ 26.8$ billion in sales and 58,282 jobs. Anderson and Platzer (2007) find that migrants have started $25 \%$ of US VC-backed public companies, and $40 \%$ of VC-backed technology firms. Wadhwa et al (2008) find that both immigrant firm founders tend to have both advanced STEM education and 'high rates of entrepreneurship and innovation' - although the same is also true of USborn founders. Working with a sample of 1300 'high-impact' technology firms and 2000 founders across the US, Hart and Acs (2011) find around 16\% of firms have at least one immigrant founder; over three quarters of these are now US citizens.

Third, some US econometric studies try to identify a 'skilled migrant' effect on entrepreneurial outcomes. Hunt $(2011 ; 2013)$ performs a number of individual-level analyses on skilled migrants. Looking at the 2003 US National College Survey, she finds that immigrants are more likely to start companies than similar natives, and those who entered on a student/trainee or a temporary work visa have a large advantage over natives in wages, patenting, and publishing. Immigrants' higher education and field of study explain much of this. Analysis of the 2009 and 2010 American Community Surveys suggests that 'immigrants from the highest income countries are the best and brightest workers.' Similarly, Kahn et al (2013) use survey data on US scientists, finding that immigrants are more likely to become 'science entrepreneurs' even after controlling for preferences, education, study field, demographics and time effects. 
A few studies attempt to explore spillover effects of immigrant entrepreneurs on their firms and the wider economy. Hart and Acs (2011) perform ANOVA on their 'high-impact' firms sample, finding similar levels of economic and technological performance between firms with migrant founders and those without. Immigrant-founded firms are more likely to report that they have a strategic relationship with a foreign firm. In calibration exercises, Duleep et al (2012) find positive links from skilled migrants to job creation, business entry and immigration across US sectors and the US workforce. Conversely, another calibration model by Bound et al (2013) finds negative effects of immigrant computer scientists on the wages and employment rates of US residents during the late 1990s.

Studies from other countries suggest salient differences between migrant groups and national contexts. Schuetze and Antecol (2007) use a Borjas-type model to look at self-employment among new migrants in Australia and Canada. They find self-employment rates for a given cohort typically catch natives within 10-20 years of arrival. Institutional and market structure factors are the most substantial determinants, although policy differences play a role at the margin. Georgarakos and Tatsirimos (2009) suggest that Mexican and other Hispanic immigrants to the US tend to move into entrepreneurship from unemployment or inactivity. Guerra and Patuelli (2011) find significant spatial network externalities between migrant entrepreneurs in Swiss municipalities, and some urban-rural differences. For Denmark, Marino et al (2012) find that workforce ethnic diversity leads to entrepreneurship in financial and business services.

\section{Implications and evidence for the UK}

What do these results imply for the UK? They suggest that the presence of large, skilled diasporas is likely to have positive effects on levels of entrepreneurship (and on other economic outcomes we care about). Non-EEA migrant communities - such as entrants from India, China and other south/east Asian countries - may be particularly important players as they are in the US, with other sending countries much less prominent contributors of skilled people. Notably, migrant entrepreneurs enter through the migration system but also through higher education.

However, there are specific features of the US experience that may not transfer to the UK: in particular, the importance of Cold War defence funding in generating a critical mass of science and engineering activity, US global leadership in a large number of technology/research fields, and the perception of an enterprise-friendly culture in the States. In skilled sectors where the UK has some comparative advantage - for instance, parts of the creative and digital economy, as well as some parts of science and engineering - there may be more of a gravitational pull for skilled migrants. We might also expect to see spatially concentrated inflows to centres of research excellence, and to cities with 
the biggest market opportunities. (Given current economic conditions in some southern European countries, we might expect similar skilled inflows from within the EEA.)

The available UK evidence bears out some of these points. Levie (2007) uses data from the GEM survey to look at individual-level determinants of entrepreneurship in the UK. OLS regressions show migrant status increases the odds of entrepreneurial activity, but that minority ethnic status only has a marginal effect. Working with a repeat cross-section of London firms, Nathan and Lee (Forthcoming) find suggestive evidence linking migrant status to proactive entrepreneurship.

Other studies suggest that UK-specific cultural factors may constrain the impact of migrant entrepreneurs. Godley (2001) is a historical analysis comparing Jewish immigrants in London and New York. He finds that the latter group were more likely to move into entrepreneurial occupations, a fact he ascribes to differences in the two cities' cultures - and specifically a 'relatively antientrepreneurial culture' in London. Along similar lines, Fairlie et al (2012) compare economic outcomes for skilled Indian-origin communities in latter-day UK, Canada and the US, using OLS regressions on Census data. They find that Indian entrepreneurs in the US have above-average business incomes; around $50 \%$ of the difference is explained by education, and around $10 \%$ by differences in industry choice. By contrast, Indian-origin entrepreneurs in the UK and Canada are less well-educated, have lower than average incomes but are more likely to hire employees.

There is also a long-standing UK empirical literature on 'ethnic entrepreneurship', largely small-scale / explorative case studies (Basu 1998; Basu and Goswami 1999; Clark and Drinkwater 2000; Basu 2002; Ruef, Aldrich et al. 2003; Basu 2004; Jamal 2005; Altinay and Altinay 2008; McEvoy and Hafeez 2009; Clark and Drinkwater 2010 ; Crick and Chaudhry 2010; Wang 2010; Wang and Altinay 2012). The most relevant points emerging from this literature are: migrant status / ethnicity is important to entrepreneurial outcomes; it is hard to disentangle from intervening factors, such as class, education, financial resources, strengths of networks; and there are substantial differences between migrant communities / co-ethnic groups' resources, and thus in their levels of entrepreneurial activity.

\section{2 / Investment}

There is now a substantial empirical literature on skilled migrants, investment and trade. These tend to focus on cross-country analyses of aggregate trade and FDI flows. There are fewer studies looking at the individual/group level, and nothing that we are aware of on individuals' investment decisions.

Three main findings emerge from the international empirics. First, several studies suggest that international investors pass on knowledge and expertise to firms they are involved with. For instance, 
Markusen and Trofimenko (2009) use plant-level data from Colombia to show significant learning externalities from foreign trainers to local workers, which raise native wages and value-added. Similarly, Malchow-Møller (2011) et al use a diff-in-diff strategy to show that Danish firms which hired foreign experts became more productive and increased their exports of goods and services. Giannetti et al (2012) look at firms in China who hire directors with foreign experience (returning migrants). They show that firms with such directors have higher valuation, productivity and profitability; better corporate governance, and higher levels of international market activity. Nielsen (2010) looks at demographic diversity in founding teams for US technology start-ups, showing a correlation between diversity and subsequent foreign market entry (and after that, higher levels of business performance). Many technology sector investors, especially in the US are former serial entrepreneurs who bring both financial and human capital to their portfolios (Kerr, Lerner et al. 2010).

These knowledge spillovers may also operate inside large firms. Foley and Kerr (2011) suggest that skilled migrants working in multinationals help those firms expand and co-ordinate investment activity in their native countries. Using data for 645 US MNEs in 45 countries, they show that increases in 'ethnic patenting' are linked to rising shares of affiliate activity in the relevant sending countries, helping those firms become more competitive.

Second, skilled migrant presence changes the balance of $\mathrm{VC}$ funding and equity holdings, much of which will be driven by individual investor decisions. Leblang (2011) and Pandya and Leblang (2012) focus on venture capital investments. Using cross-sectional data, they show significant associations between diaspora network presence and the level of VC flows from US investors. They suggest these results derive both from US-based migrants, and from diaspora members advising US VC firms about opportunities in sending countries. Similarly Foad (2011) looks at equity holdings data for 28 countries between 1997 and 2004. Using a gravity model and instruments, he shows that immigration helps increase foreign equity holdings and reduced home bias. The effects are strongest within the Eurozone, and disappear for less developed countries. Foad argues that reduced home bias in equity positions represents a substantial welfare gain, reducing risk and improving matching.

Third, and, building on the seminal paper by Rauch and Trindade (2002), a number of studies show positive effects of skilled migrants on trade and FDI flows, especially for differentiated goods. For instance, Egger et al (2012) use a quasi-experimental approach for 100 countries between 1991 and 2000 , showing that highly concentrated skilled (or unskilled) migrants induce higher trade flows particularly for differentiated goods. Mundra (2012) focuses on immigrant occupational structure, finding that higher shares of migrants in professional occupations significantly increases trade flows between the US and trading partner countries - particularly for differentiated goods. Peri and Requena (2010) focus on trade for Spanish provinces, 1995-2008, finding that immigration significantly raises 
trade - particularly for differentiated goods and for countries culturally distant from Spain. A related cluster of empirical studies look at FDI flows: Kugler and Rapoport (2007) show that skilled migration from a country helps raise future FDI inflows to that country, and suggest that skilled migrants and FDI flows are complementary trade components (while unskilled migrants are substitutes for FDI). Docquier and Lodigiani (2010) and Javorcik et al (2011) also show strong network externalities from large skilled diasporas on FDI inflows to sending countries.

\section{Implications and evidence for the UK}

The size and scope of the international evidence suggests that we should expect similar impacts on both individual investment decisions and wider trade/FDI flows from skilled migrant presence in the UK. In the first case, policies such as the Tier 1 (investor) programme could be expected to trigger knowledge spillovers a) from investors to portfolio firms, and b) from investors to investors, the latter showing up in patterns of $\mathrm{VC}$ finance and equity holdings.

The available evidence also implies that aggregate effects will be strongest for skilled migrant communities from countries where few or no trade relationships exist (and where information gaps are greatest), and weakest for sending countries where there are strong existing connections (and thus fewer gains to trade). In this sense, investment channels differ from entrepreneurship / innovation channels, where existing diasporic / co-ethnic connections generate the effects.

Three UK studies provide some evidence for this. Parsons (2005) projects the impact of A8 migration on EU-15 trade flows, suggesting that accession will increase imports from accession countries by $1.4 \%$ and exports by $1.5 \%$. Di Simone and Machin (2012) find some evidence of diaspora externalities, with a significant correlation between migrant stocks and trade activities in respective sending countries. Girma and $\mathrm{Yu}$ (2002) compare trade effects of migration to the UK from Commonwealth and non-Commonwealth countries. They find that non-Commonwealth migration has a significant export-enhancing effect in the UK, but there is no effect from Commonwealth country migrants. They suggest that this is because non-Commonwealth migrants bring new information to UK economic actors, reducing the costs of trade, whereas UK-Commonwealth trade patterns are already well established.

\section{3 / Innovation}

There are now a number of empirical studies linking skilled migrants, migrant/minority communities and innovation, particularly from the US. European and UK studies are thinner on the ground. 
First, a number of studies link high-skill migrants - including students - to knowledge creation. Stephan and Levin (2001), Chelleraj et al (2008) and Wadhwa et al (2008) highlight the contributions of Indo and Chinese-American scientists to US science, particularly foreign graduate students; Kerr and Lincoln (2010) identify links from skilled migrant entry to patenting by ethnic Indian and Chinese inventors; Stuen et al (2012) identify causal links between foreign PHD presence and subsequent highly-cited publications. However, Hunt (2011) and Hunt and Gauthier-Loiselle (2010) find that individual 'migrant effects' are largely explained by education and industry hiring patterns.

More broadly, some area-level studies find positive links between skilled migrant presence and innovation, for example Peri (2007) and Hunt and Gauthier-Loiselle (2010) find positive connections in US states; Ozgen et al (2012) for EU regions, or Niebuhr (2010) for German regions, the latter two using patent data. Most recently, Bosetti et al (2012) find positive effects of skilled migrant presence on patenting and researcher citations in a panel of 20 European countries, using a shift-share instrument to deal with endogeneity concerns. However, Kerr and Lincoln (2010) use US visa policy shocks to look at the local effect of skilled migrant supply on migrant patenting (positive) and natives (close to zero).

Second, there are strong empirical links from co-ethnic communities to knowledge diffusion (see Docquier and Rappoport (2012) for a recent review of the empirical literature). Many of the entrepreneurship case studies discussed previously also trace links between US-based diasporas and innovation 'home' countries such as India, China, Taiwan, Ireland and Israel (Kapur and McHale 2005; Saxenian 2006; Saxenian and Sabel 2008). Quantitative studies also identify links between coethnic communities and industrial performance in home countries (Kerr 2008), as well as the spread of 'breakthrough technologies' in US cities (Kerr 2010). Scellato et al (2012) find strong associations between the presence of internationally mobile researchers and the quality and scope of networks across the US and Europe. By contrast, Agrawal et al (2008) find that physical location is up to four times more important for knowledge diffusion than co-ethnic connections.

Third, there is some tentative evidence of diversity-innovation links. There is a large management literature testing small-sample correlations between aspects of diversity and business performance (see Page (2007) for a review). A handful of quantitative studies link ethnic diversity and innovation at group or workforce level. Some of these find correlations (Ostergaard, Timmermans et al. 2011) or causal links between team composition and product or process innovation (Ozgen, Nijkamp et al. 2011; Parrotta, Pozzoli et al. 2011). Others find no such connections (Maré, Fabling et al. 2011). A related study is Hoogendoorn and Van Praag (2012), which uses experimental evidence from Dutch students to show a positive effect of ethnic diversity on team performance. A couple of area-level 
studies also identify links between skilled migrant diversity and innovation, for example Ozgen et al (2012) for EU regions.

Two recent studies explore the distributional effects of skilled migrants on native innovation. Borjas and Doran (2012) examine how the arrival of mathematicians from the former Soviet Union affected the publications and career trajectories of their US counterparts. Moser et al (2012), using a longer time period, examine the effect of Jewish chemists exiled from Nazi Germany on patenting in US chemistry fields. The former study finds strong evidence of native crowding out (although questions remain about whether or not this was welfare-negative for the 'losers'). Using a difference in difference specification, he latter finds evidence of strong crowding-in, with the presence of émigrés leading to at least a 30\% increase in US native patenting between 1920 and 1970. As Kerr notes, some of the discrepancy may be due to field and time differences, as well as the different dependent variable, but more research is needed on this specific innovation channel.

\section{Implications and evidence for the UK}

Again, the scope of the international evidence suggests that skilled migration should induce some of these innovation effects in the UK. As with the entrepreneurship literature, the US experience implies that $\mathrm{HE}$ is an important entry point for skilled migrants who go on to innovate, both for faculty and the much larger numbers of research / postgraduates. Resulting diasporic communities are likely to help knowledge diffusion into and out of the UK; more diverse workforces and communities particularly research communities - may also accelerate knowledge generation.

There is now some suggestive UK evidence for all three channels. Gagliardi (2011) looks at connections between the migrant workforce and firm-level innovation in UK TTWAs, using a shiftshare instrument to identify causal effects. She finds significant positive effects from the share of skilled migrants to firm-level innovation, although the exact transmission mechanisms from area-level workforce characteristics to firm-level outcomes are not clear.

Three other studies look at co-ethnicity and diversity channels, although neither is able to precisely identify skilled migrant effects. Nathan (2011) looks at minority ethnic inventors in the UK, using a name-classification system to identify ethnicity from patents microdata. Building a panel of inventor activity between 1993 and 2004, and controlling for inventor-level characteristics, he finds that the diversity of inventor communities helps raise the level of individual patenting activity. He also finds suggestive evidence that high-patenting minority ethnic inventors, particularly East Asian 'stars', drive up overall patenting rates. He finds no hard evidence that ethnic inventors crowd out patenting by majority groups. 
Nathan and Lee (Forthcoming) look at migrant entrepreneurs and top-team diversity in London firms, using a repeat cross-sectional dataset and a series of robustness checks. They find that companies with diverse management are more likely to introduce new product innovations than those that are not. Top team diversity also influences sales orientation, and is particularly important for reaching international markets and serving London's cosmopolitan population. Nathan (2013) extends the analysis across England and Wales, finding positive links between top team diversity and process innovation.

\section{4 / Other production-side studies}

A number of international empirical studies directly test links between migration and productivity at firm, city and country-level, without identifying specific channels. These studies typically suggest externalities from high-skilled migrants to firm-level productivity, especially in skill-intensive environments. For example, Paserman (2008) looks at Israeli manufacturing firms in the 1990s, a period of high immigration from the former Soviet Union. He finds negative associations between immigrant share and productivity in low-tech sectors, but positive links for high-technology industries suggestive of production complementarities. For New Zealand, Maré (2011) finds positive links between local area migrant share and productivity in firms, but does not establish a causal relationship. Parotta et al (2010) and Trax et al (2012) both identify causal effects, using instruments and GMM estimation respectively. The former find that ethnic diversity helps raise TFP in Danish firms operating in trade-intensive sectors, suggesting that diaspora externalities may explain the link. The latter find strong spillover effects from workforce diversity (measured by nationality) to firmlevel productivity. They also find spillovers from diverse firms to other firms in the area, raising arealevel productivity.

At the area level, Ottaviano and Peri (2006), Peri (2012) and Peri et al (2013) look at links between migration and productivity for US cities and states. Using an area-level panel with a shift-share IV, Ottaviano and Peri find that skilled migrants help raise urban-level productivity. Peri finds a strong positive association between immigration and state-level TFP, and explains one third to one half of this link through increased task specialisation by native workers. ${ }^{5}$ Working with a panel of US cities, Peri et al show that increase in immigrant scientists and engineers lead to increased wages for US college-educated workers (inside and outside STEM sectors), which they interpret as the result of migrant-led productivity shifts. As in Peri and Sparber (2011) and Peri (2012), they find that changes in task specialisation play an important role. Working at cross-country level, Ortega and Peri (2012) use a panel of 147 countries to show that openness to immigration increases long-run income per head, with the main effect operating through a rise in receiving country TFP.

\footnotetext{
${ }^{5}$ By contrast, sector-level analysis by Quispe-Agnoli and Zavodny (2002) for US manufacturing, and a crosscountry study by Llull (2008) both find small negative links between immigration as a whole and productivity.
} 
Implications and evidence for the UK

These studies provide further evidence for the productivity-enhancing effects of skilled migration, and add to the likelihood that these effects are operating in the UK. However, they are limited to the extent that they do not identify specific channels of impact. They also say little about subsequent effects on employment: although if productivity gains allow firms to expand outputs, this should also raise firms' headcounts.

Parallel UK evidence emphasises the importance of migrant human capital. Nathan (2011) finds weak positive links between skilled migration and urban-level productivity, as proxied by wage changes in a panel of TTWAs between 1994 and 2008. Migration is instrumented with a shift-share. Kangasniemi et al (2012) compare labour productivity growth in Spain and the UK, using growth accounting techniques and a production function estimated via GMM. Growth accounting results suggest that migration has made a negative contribution to labour productivity in Spain and a 'negligible' contribution in the UK, with the difference explained by the UK's higher share of skilled migrants. Production function estimates suggest a positive long-term effect of migrants on TFP in the UK and a negative effect in Spain, explained by human capital differences and more successful assimilation policies in the UK.

\section{5 / Consumption side studies}

International evidence tends to focus on migrant communities as a whole (rather than skilled migrants), with a particular interest in prices (especially housing). For instance, Cortes (2008) and Baghdadi and Jensen (2010) use instruments to explore the impact of US migration on prices. Cortes finds a $10 \%$ increase in the share of low-skilled migrants decreases the price of labour-intensive services by $2 \%$, largely through lowering the cost of labour. Baghdadi and Jensen find similar reductions in prices for non-tradeable services, although the costs of transport and healthcare go up.

For the US, Saiz $(2007 ; 2011)$ and Saiz and Wachter (2011) find that immigration raises rents and housing values in destination cities, with population and rents rising in proportion. Within cities, the most immigrant-dense neighbourhoods have seen relatively slower prices increases, an effect attributed to native exits and increased urban-level segregation. For Spain, Gonzales and Ortega (2009) find that migrant inflows raised house prices by about $52 \%$ and is responsible for $37 \%$ of the total construction of new housing units between 1998 and 2008. For Switzerland, Degen and Fischer (2009) also find a large short-term link, with a $1 \%$ migrant inflow associated with a $2.7 \%$ increase in the price of a single-family home. By contrast, two studies using Census data find much smaller longterm effects. For Canada, Akbari and Aydede (2012) show a small but significant effect of 
immigration on house prices between 1996 and 2006; for New Zealand, Stillman and Maré (2008) find no significant connection on prices or rents between 1986 and 2006.

In this search, the only robust studies discovered on migration and the mix of goods and services are Mazzolari and Neumark (2012), which focuses on California, and Bo and Jacks (2012) for Canada. Mazzolari and Neumark find suggestive evidence of both scale and composition effects: immigration is associated with fewer stand-alone retail stores, but a greater variety of 'ethnic' restaurants. Bo and Jacks find that immigration is linked to $25 \%$ of the rise in import variety to Canada between 1988 2007, and argue this represents a substantial welfare gain to native-born Canadians.

\section{Implications and evidence for the UK}

As discussed, in theory skilled migrants are unlikely to have strong effects on the consumption side of the economy unless a) they make up the majority of migrants and b) their preferences and attitudes are very different from those of natives.

The international evidence suggests that very large migration shocks are linked to short-term price rises (for example, house prices in Spain), although longer term impacts are much smaller (as supplier respond). UK evidence on migration and prices is inconclusive. Frattini (2008) explores the causal effect of immigration on regional prices, using a shift-share instrument. He finds that migration contributed to reduced price growth in labour-intensive service sectors, but may have increased some grocery prices through demand-side effects. Sá (2011) finds a negative association between immigration and house prices at the local authority level between 2003-2010, which she suggests is driven by native outflows, but no links at the regional level. Working with a panel of urban TTWAs, Nathan (2011) also finds no association between immigration and city house prices between 1994 and 2006.

Whitehead et al (2011) focus specifically on skilled (Tier 2) migrants, and is the most directly relevant house prices study for this review. (They are unable to carry out any analysis for migrants as residential addresses were unavailable.) Tier 2 analysis is based on analysis of LFS and other public datasets for areas where Tier 2 migrants are known to cluster. They find that Tier 2 residents mostly live in private rented accommodation, with about $20 \%$ of a given cohort eventually becoming owneroccupiers. Tenure mix changes slowly, with owner-occupation rising to $45 \%$ after five years. They suggest that 'Tier 2 type' migrants are likely to raise house prices by under $1 \%$ over five years.

More broadly, we might expect to see skilled migrants shaping the local mix of goods and services, through demand channels but mainly via migrant entrepreneurship and advantages in market 
knowledge. There is plenty of anecdotal and case study evidence of this in the UK, but we have found no systematic studies.

\section{5/ Skilled migration and cities}

As noted in Section 1, migration flows to the UK and other developed countries have been spatially uneven, with cities and urban areas experiencing the largest inflows. ${ }^{6}$ This suggests that cities may be important sites or locations for many of the wider economic impacts of migration, especially those attributable to high-skilled migrants. Note that this 'locational' argument can hold whether or not any urban-level processes are also in play. However, there are also reasons to think that cities can amplify or constrain some of the micro-level processes discussed in this review. To explore this idea, this section set out a simple spatial economy framework and identifies how skilled migration might operate on the production and consumption sides of an urban economy. It then briefly discusses the few urban-level empirical studies in this part of the literature.

\section{The spatial economy}

The basic framework for the spatial economy is that developed by Rosen (1974) and Roback (1982) (for an extensive discussion see Glaeser (2008)). Consider a system of cities in which agglomeration economies raise workers' productivity, and thus nominal wages; on the other hand diseconomies of agglomeration, such as crowding, raise the local cost of living. Cities differ in their agglomeration endowments, and in their amenity 'packages', some of which are capitalised into the cost of living (via house prices). Some sectors (such as those in the 'knowledge economy') benefit more from agglomeration economies, as do more skilled workers (Combes, Duranton et al. 2005); amenity preferences also vary across households. In 'spatial equilibrium', households sort across space so they are indifferent across locations, labour markets (wages), housing markets (cost of living) and amenity markets all clear. High-agglomeration cities tend to have higher productivity, nominal wages and housing costs. High-amenity cities also have higher housing costs, although precise effects on wages are unclear: the value of amenities is not directly observed but can be inferred from wage-cost differentials.

How does migration enter into this framework? In their classic study, Ottaviano and Peri (2006) look at the separate effects of birth country diversity on urban wages and on rents, in order to implicitly identify the value of migrants as an urban production / consumption 'amenity'.

\footnotetext{
${ }^{6}$ Many rural areas have experienced rapid rates of change, even if the resulting stock of migrants is small.
} 
As we have seen, migrants - especially skilled migrants - can represent a production amenity for firms in the city via their effects on productivity, innovation, investment and entrepreneurship. On the average, positive affordances of skilled migrants will raise productivity in urban firms, leading to higher average nominal wages. Skilled migrants complement skilled natives, so that the latter experience the greatest relative wage gains: this is the opposite of the prediction in a neo-classical, perfect-substitutes model. ${ }^{7}$ As wages rise, however, natives and migrants from other location may sort into the city. This may reinforce production-side amenities further; but nominal wage gains may be progressively offset by rising costs since urban crowding and congestion will also increase. In particular, we may see cost increases of inelastically-supplied goods such as housing (Saiz 2007).

On the consumption side, migrants may also represent an urban consumption amenity, which positively or negatively affects households' utility (Ottaviano and Peri 2006). For example, cities may have a liberal, tolerant 'creative class' with a taste for diversity and cosmopolitanism (Florida 2002); alternatively native households may dislike the new arrivals and select out of the area (Borjas 2006). Positive (negative) consumption amenity effects of migrants should translate directly into rising (falling) local costs of living, especially housing costs.

\section{Empirics: area-level studies}

It is not easy to separate out the role of skilled migrants in this urban-level framework, or the channels by which they might affect urban outcomes. As the discussion above suggests, intuitively the presence of high-skilled migrants should be most visible as a production amenity for urban firms and native workers. Using a panel of US metro areas, Ottaviano and Peri (2006) identify a positive effect of migrant diversity on urban wages, which they interpret as a production amenity which delivers relative wage gains to skilled natives. They also find a positive effect of diversity on urban rents, consistent with either an increased demand channel or a consumption amenity (they are unable to separate the two). Bellini et al (2008) conduct parallel analysis for EU regions, finding positive effects of migrant diversity on local wages and restaurant prices but are unable to run models for skilled migrant specifically. In a further replication Nathan (2011) uses a panel of UK functional economies, finding weak positive effects of migrant diversity on skilled native wages, and some evidence of spillovers from skilled migrants to skilled natives.

Other papers have combined an urban-level outcomes framework with some exploration of the microfoundations. Peri et al (2013) find that an increase in foreign scientists and engineers leads to urbanlevel wage rises and also rising house prices. They explain the former as a production amenity

\footnotetext{
${ }^{7}$ If wage gains for skilled workers lead to further spillovers in non-tradeable service sectors (via increased discretionary spending), there may also be employment gains for lower-skilled natives.
} 
operating through clustering of human capital (including crowding-in of skilled natives), diversity effects and more efficient migrant-native task specialisation. Peri and Sparber (2011) similarly find evidence for task shifts, with skilled natives responding to the arrival of skilled migrants by moving into occupations with less analytical and more communicative content. Kerr (2009) finds higher patenting growth in cities with larger shares of immigrant scientists and engineers in the 'tech' labour force, with information flows through co-ethnic communities assisting knowledge spillovers at the urban level, operating alongside mobile firms shifting into clusters.

It is less clear how skilled migrants might figure on the consumption side of urban economies: however, a number of housing cost studies have also been done at area level which provide evidence on the overall shape of consumption /demand effects. Cross-country results are not conclusive, consistent with native preferences varying substantially between and within study areas. Saiz (2007; 2011) and Saiz and Wachter (2011) find that US immigration raises rents and housing values in destination cities, but also finds slower price rises in the most immigrant-dense neighbourhoods, consistent with migration being a negative consumption amenity.

For Spain, Gonzales and Ortega (2009) find that migrant inflows raised house prices by about $52 \%$ between 1998 and 2008. Working with similar data, Sanchis-Guarner (2013) also finds positive effects of migrants on house prices, with evidence of crowding-in of natives consistent with a positive consumption channel. Sá (2011) finds a negative association between immigration and house prices at the local authority level between 2003-2010, which she suggests is driven by native outflows, but no links at the regional level. Working with a panel of urban TTWAs, Nathan (2011) also finds no association between immigration and city house prices between 1994 and 2006. Bakens et al (2013) find a positive overall effect of cultural diversity on housing prices in Dutch cities; but this effect is negative after controlling for spatial sorting. They attribute this to a negative effect of immigrantinduced diversity on 'neighbourhood quality', which outweighs the positive consumption amenity also in play.

\section{6/ Discussion}

This paper surveys the rapidly growing body of research on the economic impacts of migrants beyond the labour market, which I dub the 'wider impacts of migration' literature. These studies typically site migrant impact channels within endogenous growth frameworks, and emphasise the importance of skilled migrants, as well as other forms of migrant 'capital': financial, social and cultural. The paper 
builds a simple framework to explore the wider impacts literature, setting out a series of channels on the 'production side' and the 'consumption side' of a host country economy.

On the production side, skilled migrants may influence productivity and its drivers, such as entrepreneurship, investment and innovation. In theory these impacts are ambiguous. Skilled migrants may act as a production complementarity in firms or teams, and/or offer network externalities through diasporas or other forms of co-ethnic group. Conversely, more diverse groups or teams may be (internally) constrained through lower trust or diminished social capital; co-ethnic groups may be (externally) constrained by discrimination or country-specific institutional factors. Over time, pros may come to outweigh cons, or vice versa. Distributional channels are less well established in the literature, but it is clear that effects on the average can hide gains and losses for native workers and firms (and for other migrants).

On the consumption side, skilled migration may affect (local) prices, product / service mix, and public service usage. In practice, skilled migrants, being a small proportion of the overall migrant population, are unlikely to have substantial direct effects. However, a skilled migrant channel may operate on through the interaction of production side comparative advantage and new (migrantdriven) sources of consumer demand.

Migration flows to developed countries are spatially uneven, with cities and urban areas typically experiencing the largest inflows. There are reasons to think that urban location may also amplify or constrain skilled migrant impact channels, through a combination of demographics and features of the urban economy. Production-side advantages from skilled migration may interact with urban agglomeration economies, raising productivity and nominal wages; further inflows may then increase competition for resources, raising local costs. Similarly, diversity from migration may represent a consumption (dis)amenity, especially for cities with cosmopolitan (less tolerant) populations; this should translate into rising (falling) costs of living, especially housing costs.

The complexity of these channels implies that most empirical studies will tend to observe the net effects of skilled migrants, although some researchers may be able to trace individual channels in detail. Certainly, the number of empirical studies is still small, and the wider economic impacts of skilled migrants are under-explored.

The most well-established literature links skilled migrants, diasporas and patterns of investment (Docquier and Rapoport 2012). A number of studies find positive causal links from the presence of skilled migrant to country-level bilateral investment levels / patterns. The evidence suggests that aggregate effects are highest for sending countries where there is no / little previous trade, so that 
gains to trade are biggest. However, the bulk of these studies focus on effects for sending countries, or on overall global flows, so that effects of the investment channel on host countries are still poorly covered.

The largest body of host country impacts work is for the USA (Kerr 2013). Descriptive studies suggest that skilled migrants, especially those of South / East Asian origin, make significant contributions to the science and technology fields, both through innovative activity and entrepreneurship. A number of firm and area-level studies also identify skilled migrant impacts on labour and firm productivity. Conversely, consumption side studies tend to link migration (as a whole) to rising prices, and to greater variety in non-tradable goods. As noted above, the impacts of skilled migrants are harder to identify, but one recent working paper does identify specific links from migrant STEM workers to higher house prices for skilled natives (Peri, Shih et al. 2013).

The empirical literature in European countries and the rest of the world is rather sparser. Results are also more mixed, reflecting the much greater heterogeneity in migrant levels and flows; sending countries and communities; and receiving country institutions. These three factors are likely to interact for a given context, and will also reflect wider historical, cultural and economic links between sending and receiving communities. All of this makes generalisations difficult: but within the EU, at least, studies typically find small net positive effects of high skilled migrants on innovation, particularly through workforce diversity and in export-intensive sectors. The pattern of results for entrepreneurship and investment is harder to establish, although the qualitative and case study literature provides suggestive evidence of the importance of migrant entrepreneurship in a number of European countries.

As this survey makes clear, there are a number of large under-explored areas for future research. Many of the basic 'wider impact' channels are well-established in theory, but poorly understood in practice. There is also a basic research gap between the USA and the rest of the developed world, with more studies needed in European and other OECD countries. Beyond the broad gaps mentioned above, I conclude by picking out a few more specific issues here.

First, on the production side, we need a much better understanding of how skilled migrant channels operate at different scales, from informal groups, formal teams and firms to cities. Within the firm, we also need to clarify channels in different parts of organisational space: we have suggestive evidence of distinct links in senior management and the wider workforce, for example, but much more research is needed to ground these. 
Second, employers' response to skilled migrant flows is also poorly understood. We have some evidence (from the USA) of manufacturing employers swapping out capital investment for more labour-intensive modes of production, for example, but such employer response strategies need to be better tested in other sectors and countries. As Kerr (2013) notes, we also need to know much more about shifts in task, field and career choices of skilled natives and migrants after a migration shock, and in many cases will need to develop new, fine-grained data to explore these channels.

Third, on the consumption side, as we have noted, it is not straightforward to identify direct impacts of skilled migrants. But more research is needed to explore both the role of migrant entrepreneurs outside the science and technology sectors, and the interaction between migrant entrepreneurship and the local non-tradeables mix.

Fourth, the quality aspect of skilled migrant channels (for instance, the social value of inventions or the value-added of new migrant businesses) is more or less untouched research space. Some studies have looked at the quality of patents via citations analysis, or the presence of migrant scientists in scientific halls of fame, but broader measures of societal value have not yet been properly explored.

Fifth, and related to this, the distributional impacts of skilled migrants need to better theorised empirically addressed. The few studies that exist show very different outcomes, suggesting that technological / industrial context may play crucial mediating roles, but as yet we have very little firm knowledge.

Addressing these knowledge gaps will not only improve researchers' understanding of the wider economic impacts of migration, it will also help policymakers design better-grounded immigration policy. Conversely, immigration policy design itself is also an under-used space for research. A number of American studies productively use aspects of the immigration regime for skilled migrants (such as H1B quotas and lotteries) to identify causal impacts of skilled migration. Researchers in other countries, including the UK, ought to be able to do the same, exploiting features of points-based entry systems and entry competitions (such as start-up visa schemes). 


\section{REFERENCES}

Acs, Z. and L. Szerb (2007). "Entrepreneurship, Economic Growth and Public Policy." Small Business Economics 28(2-3): 109-122.

Acs, Z. J., D. Audretsch, et al. (2004). The Missing Link: The Knowledge Filter and Entrepreneurship in Endogenous Growth. CEPR Discussion Paper No. 4783. London, CEPR.

Aghion, P., N. Bloom, et al. (2005). "Competition and Innovation: An Inverted-U Relationship." The Quarterly Journal of Economics 120(2): 701-728.

Aghion, P., R. Blundell, et al. (2009). "The Effects of Entry on Incumbent Innovation and Productivity." Review of Economics and Statistics 91(1): 20-32.

Aghion, P., M. Dewatripont, et al. (2012). Industrial Policy and Competition. National Bureau of Economic Research Working Paper Series. Cambridge, Mass, NBER. No. 18048.

Agrawal, A., D. Kapur, et al. (2008). "How do spatial and social proximity influence knowledge flows? Evidence from patent data." Journal of Urban Economics 64(2): 258-269.

Akbari, A. H. and Y. Aydede (2012). "Effects of immigration on house prices in Canada." Applied Economics 44(13): 1645-1658.

Aldrich, H. E. and R. Waldinger (1990). "Ethnicity and Entrepreneurship." Annual Review of Sociology 16: 111-135.

Alesina, A. and E. L. Ferrara (2005). "Ethnic Diversity and Economic Performance." Journal of Economic Literature 43(3): 762-800.

Altinay, L. and E. Altinay (2008). "Factors influencing business growth: the rise of Turkish entrepreneurship in the UK." International Journal of Entrepreneurial Behaviour \& Research 14(1): 24 - 46.

Anderson, S. and M. Platzer (2007). American Made: The Impact of Immigrant Entrepreneurs and Professionals Arlington, National Venture Capital Association.

Audretsch, D. and M. Feldman (1996). " R\&D Spillovers and the Geography of Innovation and Production." American Economic Review 86: 630-640.

Baghdadi, L. and M. Jansen (2010). "The Effects of Temporary Immigration on Prices of Non Traded Goods and Services." Journal of Economic Integration 25(4): 754-782.

Bakens, J., P. Mulder, et al. (2013). "ECONOMIC IMPACTS OF CULTURAL DIVERSITY IN THE NETHERLANDS: PRODUCTIVITY, UTILITY, AND SORTING*." Journal of Regional Science 53(1): 8-36.

Basu, A. (1998). "An Exploration of Entrepreneurial Activity among Asian Small Businesses in Britain." Small Business Economics 10(4): 313-326. 
Basu, A. (2002). "The Interaction between Culture and Entrepreneurship in London's Immigrant Businesses." International Small Business Journal 20(4): 371-393

Basu, A. (2004). "Entrepreneurial aspirations among family business owners: An analysis of ethnic business owners in the UK." International Journal of Entrepreneurial Behaviour \& Research 10(1/2): 12-33.

Basu, A. and A. Goswami (1999). "South Asian entrepreneurship in Great Britain: factors influencing growth." International Journal of Entrepreneurial Behaviour \& Research 5(5): $251-275$.

Baycan-Levent, T. and P. Nijkamp (2009). "Characteristics of migrant entrepreneurship in Europe." Entrepreneurship \& Regional Development 21(4): 375-397.

Bellini, E., G. Ottaviano, et al. (2008). Cultural Diversity and Economic Performance: Evidence from European Regions. HWWI Research Paper 3-14. Hamburg, Hamburg Institute of International Economics.

Berliant, M. and M. Fujita (2009). "Dynamics of knowledge creation and transfer: The two person case." International Journal of Economic Theory 5(2): 155-179.

Bo, C. and D. S. Jacks (2012). Trade, Variety, and Immigration. National Bureau of Economic Research Working Paper Series 17693. Cambridge, Mass, NBER. No. 17963.

Bonacich, E. (1973). "A Theory of Middleman Minorities." American Sociological Review 38(5): 583-594.

Borjas, G. (1987). "Self-Selection and the Earnings of Immigrants." American Economic Review 77: 531-553.

Borjas, G. (2006). "Native Internal Migration and the Labor Market Impact of Immigration." Journal of Human Resources XLI(2): 221-258.

Borjas, G. and K. Doran (2012). "The Collapse of the Soviet Union and the Productivity of American Mathematicians." Quarterly Journal of Economics 127 (3): 1143-1203. .

Borjas, G. J. and K. B. Doran (2012). Cognitive Mobility: Labor Market Responses to Supply Shocks in the Space of Ideas. National Bureau of Economic Research Working Paper Series 18614. Cambridge, MA, NBER. No. 18614.

Bosetti, V., C. Cattaneo, et al. (2012). Migration, Cultural Diversity and Innovation: A European Perspective. Working Paper 2012.069. Milan, FEEM.

Bound, J., B. Braga, et al. (2013). Recruitment of Foreigners in the Market for Computer Scientists in the US. Working paper.

Card, D. (2005). "Is the New Immigration Really So Bad?" The Economic Journal 115(November): 300-323.

Card, D. (2010). How Immigration Affects US Cities. Making Cities Work: Prospects and Policies for Urban America. R. P. Inman. Princeton, Princeton University Press. 
Chellaraj, G., K. Maskus, et al. (2008). "The Contribution of International Graduate Students to U.S. Innovation." Review of International Economics 16(3): 444-462.

Chiswick, B. (2005). High Skilled Immigration in the International Arena IZA Discussion Paper No. 1782. Bonn, IZA.

Clark, K. and S. Drinkwater (2000). "Pushed out or pulled in? Self-employment among ethnic minorities in England and Wales." Labour Economics 7(5): 603-628.

Clark, K. and S. Drinkwater (2010). "Recent trends in minority ethnic entrepreneurship in Britain " International Small Business Journal 28: 136-146.

Combes, P.-P., M. Lafourcade, et al. (2005). "The trade-creating effects of business and social networks: evidence from France." Journal of International Economics 66(1): 129.

Combes, P. P., G. Duranton, et al. (2005). "Agglomeration and the adjustment of the spatial economy§." Papers in Regional Science 84(3): 311-349.

Cortes, P. (2008). "The Effect of Low-Skilled Immigration on U.S. Prices: Evidence from CPI Data." Journal of Political Economy 116(3): 381-422.

Crick, D. and S. Chaudhry (2010). "An investigation into UK-based Asian entrepreneurs' perceived competitiveness in overseas markets." Entrepreneurship \& Regional Development 22(1): 5-23.

De Simone, G. and M. Manchin (2012). "Outward Migration and Inward FDI: Factor Mobility between Eastern and Western Europe." Review of International Economics 20(3): 600-615.

Degen, K. and A. Fischer (2009). Immigration and Swiss House Prices. CEPR Discussion Paper no. 7583. London, Centre for Economic Policy Research.

Department of Innovation Universities and Skills (2008). Innovation Nation. London, Department of Innovation, Universities and Skills.

Docquier, F. and E. Lodigiani (2010). "Skilled Migration and Business Networks." Open Economies Review 21(4): 565-588.

Docquier, F. and H. Rapoport (2012). "Globalization, Brain Drain, and Development." Journal of Economic Literature 50(3): 681-730.

Drori, I., B. Honig, et al. (2009). "Transnational Entrepreneurship: An Emergent Field of Study." Entrepreneurship Theory and Practice 33(5): 1001-1022.

Duleep, H. O., D. Jaeger, et al. (2012). How Immigration May Affect U.S. Native Entrepreneurship: Theoretical Building Blocks and Preliminary Results. IZA Discussion Paper 6677. Bonn, IZA.

Duranton, G. and D. Puga (2001). "Nursery Cities: Urban Diversity, Process Innovation and the Life Cycle of Products." American Economic Review 91(5): 1454-1477.

Dustmann, C., A. Glitz, et al. (2008). "The labour market impact of immigration." Oxford Review of Economic Policy 24(3): 477-494. 
Edin, P.-A., P. Frederiksson, et al. (2003). "Ethnic Enclaves and the Economic Success of Immigrants: Evidence from a Natural Experiment." Quarterly Journal of Economics 118(1): 329-.

Egger, P., D. R. Nelson, et al. (2012). "The Trade Effects of Skilled versus Unskilled Migration."

Fagerberg, J. (2005). Innovation: A guide to the literature. The Oxford Handbook of Innovation. J. Fagerberg, D. Mowery and R. Nelson. Oxford, OUP: 1-27.

Fairlie, R., H. Krashinsky, et al. (2012). Indian Entrepreneurial Success in the United States, Canada, and the United Kingdom. Research in Labor Economics. S. W. Polachek and K. Tatsiramos, Emerald Group Publishing Limited: 285-318.

Florida, R. (2002). The Rise of the Creative Class. New York, Basic Books.

Foad, H. (2011). "Immigration and equity home bias." Journal of International Money and Finance 30(6): 982-998.

Foley, C. F. and W. R. Kerr (2011). Ethnic Innovation and U.S. Multinational Firm Activity. National Bureau of Economic Research Working Paper Series. Cambridge, Mass., NBER. No. 17336.

Foley, C. F. and W. R. Kerr (2013). "Ethnic Innovation and U.S. Multinational Firm Activity." Management Science 59(7): 1529-1544.

Frattini, T. (2008). Immigration and Prices in the UK. mimeo. London, UCL.

Fujita, M. and S. Weber (2003). Strategic Immigration Policies and Welfare in Heterogenous Countries. Institute of Economic Research Working Papers. Kyoto, Kyoto University.

Gagliardi, L. (2011). Does Skilled Migration Foster Innovative Performance? Evidence from British Local Areas. SERC Discussion Paper DP0097. London, SERC.

Georgarakos, D. and K. Tatsiramos (2009). "Entrepreneurship and survival dynamics of immigrants to the U.S. and their descendants." Labour Economics 16(2): 161-170.

George, A., M. Lalani, et al. (2012). Skilled immigration and strategically important skills in the UK economy. Report for the Migration Advisory Committee. London, NIESR.

Giannetti, M., G. Liao, et al. (2012). The Brain Gain of Corporate Boards: A Natural Experiment from China. CEPR Discussion Paper DP9190. London, CEPR.

Girma, S. and Z. Yu (2002). "The link between immigration and trade: Evidence from the United Kingdom." Weltwirtschaftliches Archiv 138(1): 115-130.

Glaeser, E. (2008). Cities, Agglomeration and Spatial Equilibrium. Oxford, OUP.

Godley, A. (2001). Jewish Immigrant Entrepreneurship in New York and London, 18801914: Enterprise and Culture,. Basingstoke, Palgrave MacMillan.

Gonzalez, L. L. and F. Ortega (2009). Immigration and housing booms: Evidence from Spain. Economics Working Papers. Barcelona, Department of Economics and Business, Universitat Pompeu Fabra. 
Gordon, I., C. Whitehead, et al. (2007). The Impact of Recent Immigration on the London Economy. London, City of London Corporation.

Guerra, G. and R. Patuelli (2011). The Influence of Role Models on Immigrant SelfEmployment: A Spatial Analysis for Switzerland. Quaderni - Working Paper DSE N ${ }^{\circ}$ 745. Bologna, University of Bologna Department of Economics.

Hanson, G. H. (2012). Immigration, Productivity and Competitiveness in American Industry. Competing for Talent: The United States and High-Skilled Immigration. Washington DC, American Enterprise Institute.

Hart, D. M. and Z. J. Acs (2011). "High-Tech Immigrant Entrepreneurship in the United States." Economic Development Quarterly 25(2): 116-129.

Honig, B., I. Drori, et al., Eds. (2010). Transnational and Immigrant Entrepreneurship in a Globalized World. Toronto, University of Toronto Press.

Hoogendoorn, S. M. and M. van Praag (2012). Ethnic Diversity and Team Performance: A Field Experiment. IZA Discussion Paper 6731. Bonn, IZA.

Huber, P., A. Iara, et al. (2010). Highly Skilled Migration: A survey of the economic literature Migration, Skills and Productivity. P. Huber, M. Landesmann, C. Robinson and R. Stehrer. Vienna, WIIW.

Huber, P., M. Landesmann, et al. (2010). Migration, Skills and Productivity. Research Reports 365. Vienna, Vienna Institute for International Economic Studies.

Hunt, J. (2011). "Which Immigrants Are Most Innovative and Entrepreneurial? Distinctions by Entry Visa." Journal of Labor Economics 29(3): 417-457.

Hunt, J. (2013). Are Immigrants the Best and Brightest U.S. Engineers? National Bureau of Economic Research Working Paper Series No. 18696. Cambridge, Mass, NBER.

Hunt, J. and M. Gauthier-Loiselle (2010). "How Much Does Immigration Boost Innovation?" American Economic Journal: Macroeconomics 2(2): 31-56.

Jacobs, J. (1969). The Economy of Cities. London, Vintage.

Jaffe, A. (1996). "Economic analysis of research spillovers: Implications for the Advanced Technology Program." Economic Analysis: 1-14.

Jaffe, A. and M. Trajtenberg (2002). Patents, Citations, and Innovations. Cambridge, MA, MIT Press.

Jaffe, A. B., M. Trajtenberg, et al. (1993). "Geographic Localization of Knowledge Spillovers as Evidenced by Patent Citations." The Quarterly Journal of Economics 108(3): 577598.

Jamal, A. (2005). "Playing to win: an explorative study of marketing strategies of small ethnic retail entrepreneurs in the UK." Journal of Retailing and Consumer Services 12(1): 1-13.

Javorcik, B. S., Ç. Özden, et al. (2011). "Migrant networks and foreign direct investment." Journal of Development Economics 94(2): 231-241. 
Kahn, S., G. La Mattina, et al. (2013). "Hobos", "Stars" and Immigrant Entrepreneurship. Working paper.

Kangasniemi, M., M. Mas, et al. (2012). "The economic impact of migration: productivity analysis for Spain and the UK." Journal of Productivity Analysis 38(3): 333-343.

Kapur, D. and J. McHale (2005). Sojourns and Software: Internationally mobile human capital and high tech industry development in India, Ireland and Israel. From Underdogs to Tigers: The Rise and Growth of the Software Industry in Brazil, China, India, Ireland and Israel. A. Arora and A. Gambardella. Oxford, OUP: 236-274.

Kerr, S. P. and W. Kerr (2011). Economic Impacts of Immigration: A Survey NBER Working Paper 16736. Cambridge, MA, NBER

Kerr, W. (2008). "Ethnic Scientific Communities and International Technology Diffusion." Review of Economics and Statistics 90(3): 518-537.

Kerr, W. (2009). Breakthrough Innovations and Migrating Clusters of Innovation. NBER Working Paper 15443. Cambridge, MA, NBER.

Kerr, W. and W. Lincoln (2010). The Supply Side of Innovation: H-1b Visa Reforms and US Ethnic Invention NBER Working Paper 15768. Cambridge, Mass., NBER

Kerr, W. R. (2010). "Breakthrough inventions and migrating clusters of innovation." Journal of Urban Economics 67(1): 46-60.

Kerr, W. R. (2013). "U.S. High-Skilled Immigration, Innovation, and Entrepreneurship: Empirical Approaches and Evidence." National Bureau of Economic Research Working Paper Series No. 19377.

Kerr, W. R., J. Lerner, et al. (2010). "The Consequences of Entrepreneurial Finance: A Regression Discontinuity Analysis." National Bureau of Economic Research Working Paper Series No. 15831.

Kloosterman, R. and J. Rath (2001). "Immigrant entrepreneurs in advanced economies: mixed embeddedness further explored." Journal of Ethnic and Migration Studies 27(2): 189-202.

Kloosterman, R. and J. Rath (2003). Immigrant Entrepreneurs: Venturing Abroad in the Age of Globalisation. Oxford, Berg.

Kugler, M. and H. Rapoport (2007). "International labor and capital flows: Complements or substitutes?" Economics Letters 94(2): 155-162.

LeBlang, D. (2011). Another Link in the Chain: Migrant Networks and International Investment. Diaspora for Development in Africa. S. Plaza and D. Ratha. Washington DC, World Bank.

Levie, J. (2007). "Immigration, In-Migration, Ethnicity and Entrepreneurship in the United Kingdom." Small Business Economics 28(2): 143-169.

Lewis, E. (2011). "Immigration, Skill Mix, and Capital Skill Complementarity." The Quarterly Journal of Economics 126(2): 1029-1069. 
Lewis, E. G. (2012). "Immigration and Production Technology." National Bureau of Economic Research Working Paper Series No. 18310.

Light, I. (1984). "Immigrant and ethnic enterprise in North America*." Ethnic and Racial Studies 7(2): 195-216.

Light, I. (2004). "Immigration and ethnic economies in giant cities." International Social Science Journal 56(181): 385-398.

Llull, J. (2008). The Impact of Immigration on Productivity. CEMFI Working Paper 0802. Madrid, CEMFI.

Lucas, R. (1988). "On the Mechanics of Economic Growth." Journal of Monetary Economics 22: $3-42$.

Malchow-Møller, N., J. R. Munch, et al. (2011). Do Foreign Experts Increase the Productivity of Domestic Firms? IZA Discussion Paper 6001. Bonn, IZA.

Manacorda, M., A. Manning, et al. (2012). "The Impact of Immigration on the Structure of Male Wages: Theory and Evidence from Britain." Journal of the European Economic Association 10(1): 120-151.

Maré, D. C. and R. Fabling (2011). Productivity and Local Workforce Composition. Motu Working Paper 11-10. Wellington, NZ, Motu Economic and Public Policy Research.

Maré, D. C., R. Fabling, et al. (2011). Immigration and Innovation. IZA Discussion Paper 5686. Bonn, IZA.

Marino, M., P. Parrotta, et al. (2012). Does Labor Diversity Promote Entrepreneurship? Economics Working Papers 2012-04. Aarhus, Department of Economics and Business, Aarhus University.

Markusen, J. and A. Venables (1999). "Foreign Direct Investment as a Catalyst for Industrial Development " European Economic Review 43(2): 335-356.

Markusen, J. R. and N. Trofimenko (2009). "Teaching locals new tricks: Foreign experts as a channel of knowledge transfers." Journal of Development Economics 88(1): 120-131.

Mazzolari, F. and D. Neumark (2012). "Immigration and Product Diversity." Journal of Population Economics 25(3): 1107-1137

McCann, P. and Z. J. Acs (2011). "Globalization: Countries, Cities and Multinationals." Regional Studies 45(1): 17 - 32.

McEvoy, D. and K. Hafeez (2009). "Ethnic enclaves or middleman minority? Regional patterns of ethnic minority entrepreneurship in Britain." International Journal of Business and Globalisation 3(1): 94-110.

Moser, P., A. Voena, et al. (2012). German Jewish Emigres and US Innovation. Working paper.

Mudambi, R. (2008). "Location, control and innovation in knowledge-intensive industries." Journal of Economic Geography 8(5): 699-725. 
Mundra, K. (2012). Immigration and Trade Creation for the U.S.: The Role of Immigrant Occupation. IZA Discussion Paper 7073. Bonn, IZA.

Nathan, M. (2011). Ethnic Inventors, Diversity and Innovation in the UK: Evidence from Patents Microdata. Spatial Economics Research Centre SERCDP0092. London, SERC.

Nathan, M. (2011). The Long Term Impacts of Migration in UK Cities: Diversity, wages, employment and prices. SERC Discussion Paper SERCDP0067. London, Spatial Economics Research Centre.

Nathan, M. (2012). "After Florida: Towards an Economics of Diversity." European Urban and Regional Studies Online First(December).

Nathan, M. (2013). Top Team Demographics, Innovation and Business Performance: Findings from English Firms and Cities 2008-9. Spatial Economics Research Centre Discussion Paper SERCDP0129. London, LSE.

Nathan, M. and N. Lee (Forthcoming). "Cultural diversity, innovation and entrepreneurship: Firm-level evidence from London." Economic Geography.

Niebuhr, A. (2010). "Migration and innovation: Does cultural diversity matter for regional R\&D activity?" Papers in Regional Science 89(3): 563-585.

Nielsen, S. (2010). "Top Management Team Internationalisation and Firm Performance." Management International Review 50: 164-180.

Ortega, F. and G. Peri (2012). "The Effect of Trade and Migration on Income." National Bureau of Economic Research Working Paper Series No. 18193.

Ostergaard, C. R., B. Timmermans, et al. (2011). "Does a different view create something new? The effect of employee diversity on innovation." Research Policy 40(3): 500509.

Ottaviano, G. and G. Peri (2006). "The Economic Value of Cultural Diversity: Evidence from US Cities." Journal of Economic Geography 6: 9-44.

Ozgen, C., P. Nijkamp, et al. (2011). The Impact of Cultural Diversity on Innovation: Evidence from Dutch Firm-Level Data. IZA Discussion Paper 6000. Bonn, IZA.

Ozgen, C., P. Nijkamp, et al. (2012). Immigration and Innovation in European Regions. Migration Impact Assessment: New Horizons. P. Nijkamp, J. Poot and M. Sahin. Cheltenham, Edward Elgar.

Page, S. (2007). The Difference: How the Power of Diversity Creates Better Groups, Firms, Schools and Societies. Princeton, Princeton University Press.

Pandya, S. and D. Leblang (2012). "Deal or No Deal: Explaining the Rise of International Venture Capital Investment ".

Parrotta, P., D. Pozzoli, et al. (2010). Does Labor Diversity Affect Firm Productivity? WP 10-12. Economics Department Working Paper Series. Aarhus, Aarhus School of Business. 
Parrotta, P., D. Pozzoli, et al. (2011). The Nexus Between Labor Diversity and Firm's Innovation [sic]. NORFACE Discussion Paper 2011-5. The Hague.

Parsons, C. (2005). Quantifying the Trade-Migration Nexus of the Enlarged EU. Sussex Migration Working Paper no. 27. Falmer, Sussex Centre for Migration Research, University of Sussex

Paserman, D. (2008). Do High-Skill Immigrants Raise Productivity? Evidence from Israeli Manufacturing Firms, 1990-1999, Institute for the Study of Labor (IZA).

Peri, G. (2007). Higher Education, Innovation and Growth. Education and Training in Europe. G. Brunello, P. Garibaldi and E. Wasmer. Oxford, Oxford University Press: 56-70.

Peri, G. (2012). "The Effect Of Immigration On Productivity: Evidence From U.S. States." Review of Economics and Statistics 94(1): 348-358.

Peri, G. and F. Requena (2010). "The Trade Creation Effect of Migrants: Testing the Theory on the Remarkable Case of Spain." Canadian Journal of Economics 43(4): 14331459.

Peri, G., K. Shih, et al. (2013). STEM Workers, H1B Visas and Productivity in US Cities. Working paper.

Peri, G. and C. Sparber (2011). "Highly Educated Immigrants and Native Occupational Choice." Industrial Relations 50(3): 385-411.

Quispe-Agnoli, M. and M. Zavodny (2002). "The effect of immigration on output mix, capital, and productivity." Economic Review-Federal Reserve Bank of Atlanta 87(1): $17-28$.

Ram, M. and T. Jones (2008). "Ethnic-minority businesses in the UK: a review of research and policy developments." Environment and Planning C: Government and Policy 26(2): 352-374.

Rath, J. and R. Kloosterman (2000). "Outsiders' Business: A Critical Review of Research on Immigrant Entrepreneurship." International Migration Review 34(3): 657-681.

Rauch, J. E. and A. Casella (2003). "Overcoming Informational Barriers to International Resource Allocation: Prices and Ties." The Economic Journal 113(484): 21-42.

Rauch, J. E. and V. Trindade (2002). "Ethnic Chinese Networks in International Trade." Review of Economics and Statistics 84(1): 116-130.

Roback, J. (1982). "Wages, Rents and the Quality of Life." Journal of Political Economy 90(6): 1257-1278.

Romer, P. (1990). "Endogenous Technological Change." Journal of Political Economy 98(5): 71-102.

Rosen, S. (1974). "Hedonic Prices and Implicit Markets: Product Differentiation in Pure Competition." Journal of Political Economy 82(1): 34-55. 
Ruef, M., H. E. Aldrich, et al. (2003). "The Structure of Founding Teams: Homophily, Strong Ties, and Isolation among U.S. Entrepreneurs." American Sociological Review 68(2): 195-222.

Sá, F. (2011). Immigration and House Prices in the UK. IZA DP No. 5893. Bonn, IZA: July.

Saiz, A. (2003). "Room in the Kitchen for the Melting Pot: Immigration and Rental Prices." Review of Economics and Statistics 85(3): 502-521.

Saiz, A. (2007). "Immigration and housing rents in American cities." Journal of Urban Economics 61(2): 345-371.

Saiz, A. (2011). Immigrants, Hispanics, and the Evolution of Housing Prices in the US. Latinos and the Economy. D. L. Leal and S. J. Trejo, Springer New York: 233-251.

Saiz, A. and S. Wachter (2011). "Immigration and the Neighborhood." American Economic Journal: Economic Policy 3(2): 169-188.

Sanchis-Guarner, R. (2013). First-come first-served: immigration, native displacement and house prices in Spain. 3rd European Meeting of the Urban Economics Association. Palermo.

Saxenian, A.-L. (2002). "Silicon Valley's New Immigrant High-Growth Entrepreneurs." Economic Development Quarterly 16(1).

Saxenian, A.-L. (2006). The New Argonauts: Regional Advantage in a Global Economy. Cambridge, MA, Harvard University Press.

Saxenian, A.-L. and C. Sabel (2008). "Venture Capital in the 'Periphery': The New Argonauts, Global Search and Local Institution-Building." Economic Geography 84(4): 379-394.

Scellato, G., C. Franzoni, et al. (2012). Mobile Scientists and International Networks. NBER Working Paper Series 18613. Cambridge, MA, NBER. No. 18613.

Schuetze, H. and H. Antecol (2007). Immigration, Entrepreneurship and the Venture Start-up Process. The Life Cycle of Entrepreneurial Ventures. S. Parker, Springer US. 3: 107135.

Schumpeter, J. (1962). The Theory of Economic Development. Berlin, Springer.

Sepulveda, L., S. Syrett, et al. (2011). "Population superdiversity and new migrant enterprise: The case of London." Entrepreneurship \& Regional Development 23(7-8): 469-497.

Smallbone, D., J. Kitching, et al. (2010). "Ethnic diversity, entrepreneurship and competitiveness in a global city." International Small Business Journal 28(2): 174190.

Stephan, P. and S. Levin (2001). "Exceptional Contributions to US Science by the foreignborn and foreign-educated." Population Research and Policy Review 20: 59-79.

Stillman, S. and D. C. Maré (2008). Housing Markets and Migration: Evidence from New Zealand. Motu Working Paper 08-06, Motu Economic and Public Policy Research. 
Stuen, E. T., A. M. Mobarak, et al. (2012). "Skilled Immigration and Innovation: Evidence from Enrolment Fluctuations in US Doctoral Programmes*." The Economic Journal 122(565): 1143-1176.

Syrett, S. and L. Sepulveda (2011). "Realising the diversity dividend: population diversity and urban economic development." Environment and Planning A 43(2): 487-504.

Trax, M., S. Brunow, et al. (2012). Cultural Diversity and Plant-Level Productivity. IZA Discussion Paper 6845. Bonn, IZA.

Vertovec, S. (2007). "Super-diversity and its implications." Ethnic and Racial Studies 30(6): 1024-1054.

Wadhwa, V., A. Saxenian, et al. (2008). "Skilled Immigration and Economic Growth."

Wang, C. L. and L. Altinay (2012). "Social embeddedness, entrepreneurial orientation and firm growth in ethnic minority small businesses in the UK." International Small Business Journal 30(1): 3-23.

Wang, Q. (2010). "Immigration and Ethnic Entrepreneurship: A Comparative Study in the United States." Growth and Change 41(3): 430-458.

Whitehead, C., A. Edge, et al. (2011). The impact of migration on access to housing and the housing market: A project for the Migration Advisory Committee: FINAL REPORT. London, LSE / MAC.

Zenou, Y. (2011). Spatial versus Social Mismatch: The Strength of Weak Ties. IZA Discussion Papers 5507. Bonn, Institute for the Study of Labor (IZA).

Zhou, M. (2004). "Revisiting Ethnic Entrepreneurship: Convergencies, Controversies, and Conceptual Advancements1." International Migration Review 38(3): 1040-1074.

Zucker, L. G. and M. R. Darby (2007). Star Scientists, Innovation and Regional and National Immigration. National Bureau of Economic Research Working Paper 13547. Cambridge, Mass, NBER. 